\title{
Analisis Kesulitan Guru dalam Menerapkan Penilaian Autentik Di Sekolah Dasar Negeri
}

\author{
Fitri Ijarmanaㄹ, Elpri Darta Putra ${ }^{2}$ \\ Pendidikan Guru Sekolah Dasar Universitas Islam Riau \\ Correspondence Email : fitriijarmana@student.uir.ac.id
}

\begin{abstract}
Abstrak
Tujuan dari penelitian ini adalah untuk mendeskripsikan kendala guru dalam menerapkan penilaian autentik di Sekolah Dasar Negeri 29 Pekanbaru. Jenis penelitian ini adalah penelitian kualitatif deskriptif. Narasumber pada penelitian ini adalah kepala sekolah serta guru kelas II, guru kelas IV dan guru kelas V di Sekolah Dasar Negeri 29 Pekanbaru. Teknik pengumpulan data yang digunakan adalah wawancara, observasi dan dokumentasi. Teknik analisis data menggunakan model Milles and Huberman dengan tahapan, reduksi data, penyajian data, dan penarikan kesimpulan. Hasil penelitian menunjukkan bahwa Sekolah Dasar Negeri 29 Pekanbaru telah menerapkan penilaian autentik untuk menilai hasil belajar siswa yang meliputi penilaian sikap, pengetahuan dan keterampilan. Penilaian sikap menggunakan teknik pengamatan secara langsung (observasi) dan penilaian diri. Penilaian pengetahuan berbentuk tes tertulis, penugasan dan soal-soal di buku Lembar Kerja Siswa (LKS) . Penilaian keterampilan menggunakan teknik praktik/kinerja dan produk. Kendala yang dialami guru dalam menerapkan penilaian autentik adalah penggunaan teknik penilaian diri pada penilaian sikap siswa, penggunaan teknik tes tertulis dan penugasan pada kompetensi pengetahuan serta pengunaan teknik produk pada penilaian keterampilan.
\end{abstract}

Kata Kunci :

Guru, Penilaian Autentik, SD

\begin{abstract}
The purpose of this study is to describe the problem of teachers in applying authenticity at the 29 Pekanbaru State Elementary School. This type of research is descriptive qualitative research. The resource persons in this study were the principal and second grade teachers, fourth grade teachers and fifth grade teachers at the 29 Pekanbaru State Elementary School. Data collection techniques used are interviews, observation and documentation. The data analysis technique uses the Milles and Huberman model with stages, data reduction, data presentation, and drawing conclusions. The results showed that the Pekanbaru 29 Public Elementary School had assessed the authentic principle to assess student learning outcomes which included assessment, knowledge and skills. Attitude assessment uses direct observation techniques (observation) and self-assessment. Knowledge assessment in the form of written tests, assignments and questions in the Student Worksheet (LKS). Skills assessment using practice/performance techniques and products. The obstacles experienced by teachers in implementing authentic assessment are the use of assessment techniques on student attitudes, the use of written test techniques and assignments on knowledge competencies and the use of product techniques on skills.
\end{abstract}

Keywords :

Teacher, Authentic Assessment, SD

\section{A. PENDAHULUAN}

Pendidikan merupakan pengaruh dinamis yang mampu mengembangkan pribadi integral dalam perkembangan rohani, jasmani, susila, keterampilan, dan rasa sosial yang menuntun tumbuh kembangnya seorang siswa ${ }^{1}$. Melalui pendidikan diharapkan dapat

\footnotetext{
1 N. K. Puspa Indah Larasanty, "Meningkatkan Kompetensi Pengetahuan IPA Dengan Menggunakan Model Pembelajaran Predict Observe Explain Berbasis Berpikir Kreatif,” Jurnal
} 
meningkatkan ilmu pengetahuan, yang didapat melalui lembaga formal maupun lembaga informal dengan tujuan untuk menjadikan manusia yang berkualitas. Pendidikan formal tidak terlepas dari kurikulum maupun pembelajaran. $^{2}$

Kurikulum 2013 merupakan kurikulum baru yang berfungsi sebagai penyempurna dari kurikulum sebelumnya, yaitu Kurikulum Tingkat Satuan Pendidik (KTSP). Standar Penilaian Kurikulum 2013 bertujuan untuk menjamin perencanaan penilaian peserta didik sesuai kompetensi yang akan dicapai dan prinsip-prinsip edukatif, efektif, efisien dan sesuai dengan konteks sosial budaya dan pelaporan hasil penilaian peseeta didik secara obyektif, akuntabel dan informative.

Di dalam dunia pendidikan, guru merupakan salah satu komponen penting dalam pelaksanaan kurikulum. 3Kegiatan guru setelah melakukan proses belajar mengajar merupakan melakukan penilaian hasil belajar. Penilaian hasil belajar bertujuan untuk mengukur keberhasilan pembelajaran yang dilakukan oleh guru dan sekaligus mengukur keberhasilan peserta didik dalam penguasaan kompetensi yang telah ditentukan.

Salah satu penekanan dalam kurikulum 2013 merupakan penilaian autentik (authentic assesment). Penilaian autentik adalah pengukuran yang bermakna secara signifikan atas hasil belajar peserta didik untuk ranah sikap, keterampilan, dan pengetahuan.

Mimbar Ilmu 25, no. Vol 25, No 3 (2020): 391400.

2 Tegar Pamubdhi yuyun Dwi Haryanti, Sapriya, "Jurnal Cakrawala Pendas Pengembangan Model Penilaian Autentik 1" 7, no. 1 (2021): 27-39.

3 Warsono Warsono, "Guru: Antara Pendidik, Profesi, Dan Aktor Sosial," The Journal of Society \& Media 1 , no. 1 (2017): 1 .
Secara konseptual, penilaian autentik lebih bermakna secara signifikan dibandingkan dengan tes pilihan ganda ${ }^{4}$. Ketika menerapkan penilaian autentik untuk mengetahui hasil dan prestasi belajar belajar peserta didik, guru menerapkan kriteria yang berkaitan dengan konstruksi pengetahuan, aktivitas mengamati dan mencoba, dan nilai prestasi di luar sekolah5.

Penilaian autentik berbeda dengan penilaian tradisional. Penilaian tradisional cendrung memilih respon yang tersedia, sedangkan dalam penilaian autentik peserta didik mengerjakan suatu tugas atau proyek. ${ }^{6}$ Dalam penilaian autentik lebih memperhatikan keseimbangan antara penilaian kompetensi sikap, pengetahuan dan keterampilan yang disesuaikan dengan perkembangan karakteristik peserta didik sesuai dengan jenjangnya. Penilaian autentik, selain memperhatikan aspek kompetensi sikap (afektif) kompetensi pengetahuan (kognitif) dan kompetensi keterampilan (psikomotorik) serta variasi instrumen atau alat tes yang digunakan juga harus memperhatikan input, proses dan output peserta didik. Penilaian hasil belajar peserta didik juga harus dilakukan pada awal pembelajaran (penilaian input), selama pembelajarn (penilaian proses), dan setelah pembelajaran (penilaian output).

\footnotetext{
4 Kunandar, Penilaian Autentik (Penilaian Hasil Belajar Peserta Didik Berdasarkan Kurikulum 2013, 2015.

5 Ruslan, Tati Fauziah, and Tuti Alawiyah, "Kendala Guru Dalam Menerapkan Penilaian Autentik Di SD Kabupaten Pidie," Jurnal Ilmiah Mahasiswa Pendidikan Guru Sekolah Dasar 1, no. 1 (2016): 147-57.

6 Kunandar, Penilaian Autentik (Penilaian Hasil Belajar Peserta Didik Berdasarkan Kurikulum 2013.
} 
Akan tetapi pada penerapannya, masih banyak guru yang mengalami kendala mengenai penerapan penilaian autentik khususnya pada jenjang Sekolah Dasar. Berdasarkan hasil penelitian di salah satu Sekolah Dasar Negeri yaitu di Sekolah Dasar Negeri 29 Pekanbaru. Sekolah tersebut sudah menerapkan penilaian autentik sesuai dengan penekanan dari Kurikulum 2013. Di dalam melakukan penilaian guru-guru sudah memperhatikan aspek sikap, pengetahuan dan keterampilan yang menjadi ciri-ciri dari penilaian autentik. Namun dalam menerapkan penilaian autentik guru-guru di SDN 29 Pekanbaru masih mengalami kendalakendala, baik kendala dari guru itu sendiri maupun kendala dari siswasiswanya. Maka dari itu, tujuan penelitian ini adalah peneliti ingin mendeskripsikan bagaimana penerapan penilaian autentik serta kendalakendala guru dalam menerapkan penilaian autentik di Sekolah Dasar Ngeri 29 Pekanbaru, dengan menggunakan teknik wawancara dengan guru-guru kelas dan kepala sekolah mengenai kesulitan guru dalam menerapkan penilaian autentik. Kemudian, peneliti juga menggunakan teknik observasi. Selama proses pembelajaran peneliti melakukan pengamatan mengenai teknik penilaian yang dilakukan oleh guru.

Penelitian mengenai kendala guru dalam menerapkan penilaian autentik ini bukanlah penelitian yang pertama kali dilakukan. Sudah sangat banyak peneliti-peneliti yang melakukan penelitian mengenai kendala guru dalam menerapkan penilaian autentik. Salah satunya adalah penelitian yang dilakukan Ruslan, Dkk. Hasil penelitian menunjukkan bahwa kendala dialami oleh guru-guru di SD Kabupaten Pidie adalah banyaknya aspek yang harus dinilai dalam penilaian Kurikulum 2013. Kedua, penilaian dilakukan bersamaan dengan proses pembelajaran, sehingga membuat proses belajar mengajar menjadi kurang efektif. Ketiga, guru merasa terbebani karena harus menjumlahkan setiap nilai yang diperoleh siswa secara keseluruhan lalu mendeskripsikan nilai yang didapat tersebut per mata pelajaran 7 .

Penelitian ini berbeda atau memiliki keunikan tersendiri. Keunikan penelitian ini adalah Pertama, penelitian ini dilakukan pada saat pembelajaran daring (dalam jaringan). Sehingga data yang di dapatkan berbeda dengan penelitian sebelumnya. Kedua, penelitian ini dilakukan hanya berfokus pada salah satu Sekolah yaitu Sekolah Dasar Negeri 29 Pekanbaru.

\section{B. HASIL DAN PEMBAHASAN}

\section{Hasil Penelitian}

Kurikulum di Sekolah Dasar Negeri 29 Pekanbaru dikembangkan sesuai dengan kondisi satuan pendidikan Sekolah Dasar Negeri 29 Pekanbaru di bawah koordinasi dan supervisi pengawas satuan pendidikan dari Kantor Dinas Pendidikan Kota Pekanbaru. Pengembangan Kurikulum ini tetap berpegang pada Standar Isi dan Standar Kompetensi Lulusan dan berpedoman pada Buku Panduan Penyusunan kurikulum yang disusun oleh Badan Standar Nasional Pendidikan (BSNP), serta memperhatikan pertimbangan komite sekolah.

$\begin{array}{cccc}\text { Sekolah } & \text { Dasar } & \text { Negeri } 29 \\ \text { Pekanbaru } & \text { sudah } & \text { menerapkan }\end{array}$
kurikulum 2013 dari tahun 2018 yang

\footnotetext{
7 Ruslan, Fauziah, and Alawiyah, "Kendala Guru Dalam Menerapkan Penilaian Autentik Di SD Kabupaten Pidie." Jurnal Ilmiah Mahasiswa Pendidikan Guru Sekolah Dasar 1, no. 1 (2016): 147-57
} 
pelaksanaannya dilaksanakan secara bertahap. Di dalam penerapannya, guru-guru tetap melakukan pelatihan seperti mengutus guru/wali kelas untuk mengikuti pelatihan Kurikulum 2013. Guru tersebut akan menyampaikan kepada guru-guru di Sekolah Dasar Negeri 29 Pekanbaru dan mengembangkannya.

Pada saat peneliti melakukan penelitian pada bulan Juni 2021 sampai dengan Juli 2021, proses pembelajaran di Sekolah Dasar Negeri 29 Pekanbaru dilaksanakan secara daring (dalam jaringan) dengan memanfaatkan teknologi seperti aplikasi WhatsApp, Google Meet, Zoom. Pada saat pembelajaran berlangsung, peneliti ikut bergabung di dalam WhatsApp Group, Meet serta Zoom untuk melakukan kegiatan pengamatan (observasi) mengenai penilaian pembelajaran yang dilakukan guru.

Di Sekolah Dasar Negeri 29 Pekanbaru, guru menggunakan penilaian autentik sebagai pendekatan penilaian pembelajaran dalam kurikulum 2013. Penerapan penilaian autentik sudah sesuai dengan ciri khas penilaian autentik yaitu penilaian dengan memperhatikan aspek sikap, pengetahuan serta keterampilan siswa. Akan tetapi di dalam penerapan penilaian autentik, guru mengalami kendala terkait penerapan penilaian autentik. Berikut penjelasan lebih rinci mengenai penerapan penilaian autentik serta kendala guru dalam menerapkan penilaian autentik pada setiap kompetensi penilaian.

\section{a. Penilaian Kompetensi Sikap}

Di dalam proses pembelajaran daring (dalam jaringan), guru tetap melakukan penilaian sikap. Di Sekolah Dasar Negeri 29 Pekanbaru, guru menilai sikap siswa menggunakan penilaian diri dan observasi perilaku dalam keseharian siswa. Pada teknik penilaian diri, guru membuat format penilaian sendiri dan membagikan kepada masing-masing siswa melalui WhatsApp Group dan meminta setiap individu untuk mengisi format penilaian diri yang diberikan guru. Penilaian diri dilakukan oleh guru di akhir subtema. Sedangkan observasi perilaku dilakukan guru setiap hari. Guru mencatat sikap siswa di dalam catatan guru. Sikap yang dinilai adalah sikap siswa yang Sangat Baik dan Perlu Bimbingan. Nilai sikap siswa dijadikan acuan untuk nilai pengetahuan siswa. Jika sikap siswa baik maka guru akan menambahkan kedalam nilai pengetahuan siswa begitu juga sebaliknya, jika nilai pengetahuan siswa tinggi akan tetapi sikap siswa buruk, maka guru akan mengurangi nilai pengetahuan siswa.

\section{b. Penilaian Kompetensi Pengetahuan}

Pelaksanaan penilaian kompetensi pengetahuan di Sekolah Dasar Negeri 29 Pekanbaru dilaksanakan selama proses pembelajaran seperti tes tertulis, penugasan, dan soal-soal yang ada di buku LKS. Pada saat pembelajaran daring (dalam jaringan), guru mengirimkan soal tertulis kepada siswa, lalu siswa menjawab soal tersebut di dalam kertas selembar. Sedangkan mengenai Penilaian Mid Semester, dilaksanakan di akhir tema. Jadi setiap akhir tema akan dilaksanakan Mid semester yang soalnya berbentuk piihan ganda dan essay. Mengenai penilaian UTS dilaksanakan di tengah semester setelah selesai 2 tema, maka sekolah akan mengadakan Ujian Tengah Semester (UTS). Dan yang terakhir adalah penilaian UAS yang dilaksanakan di akhir semester, setelah siswa menyelesaikan semua tema.

c. Penilaian Kompetensi Keterampilan 
Pada penilaian kompetensi keterampilan, guru menggunakan teknik parktik/kinerja dan produk. Hal ini sesuai dengan penilaian keterampilan yang dicantumkan guru di dalam silabus yaitu praktik/kinerja, proyek, produk. Terdapat perbedaan mengenai penilaian keterampilan di kelas rendah dan di kelas tinggi. Penilaian keterampilan yang dilakukan guru di kelas rendah yaitu hanya mengambil nilai praktik siswa sedangkan di kelas tinggi guru mengambil nilai keterampilan siswa menggunakan teknik penilaian praktik/kinerja, produk, dan proyek. Akan tetapi untuk teknik proyek belum dapat dilaksanakan karena saat ini pembelajaran daring (dalam jaringan), sehingga ketika dilaksanakan hasilnya tidak akan efektif. Jadi teknik yang digunakan guru dikelas tinggi hanya praktik/ kinerja dan produk.

d. Kendala guru dalam menerapkan Penilaian Autentik

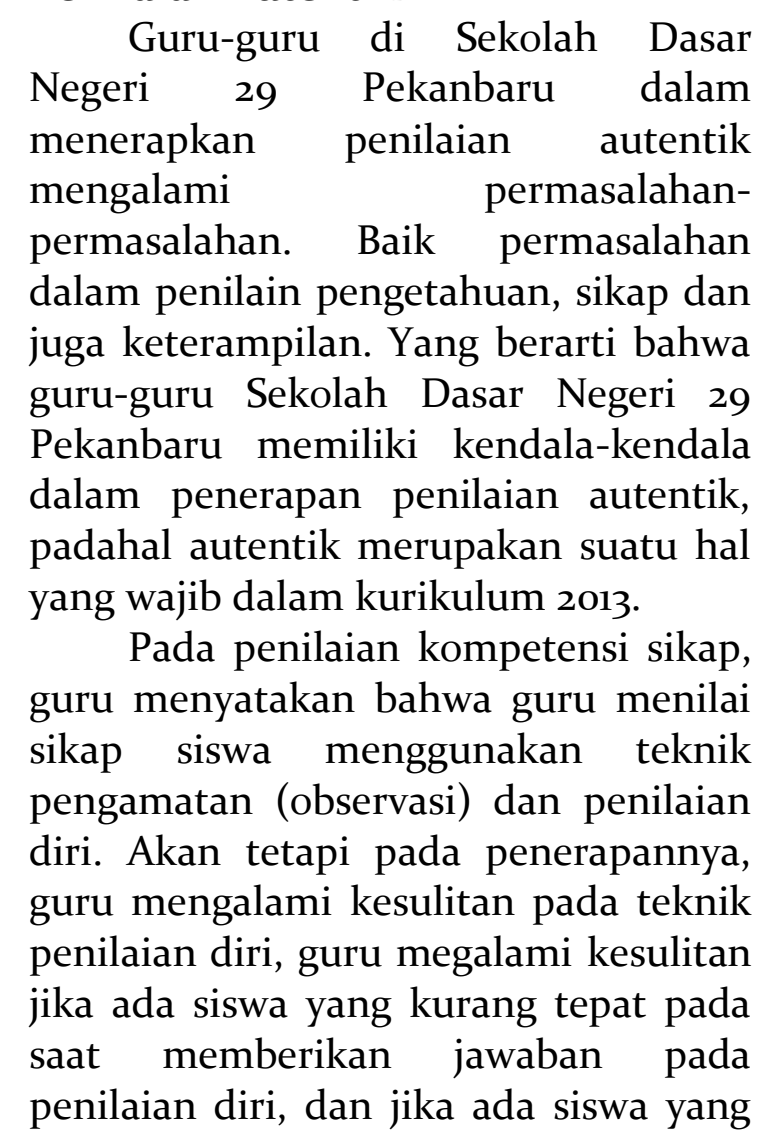

tidak jujur dalam memberikan jawaban pada penilaian diri. Sehingga nilai yang diberikan tidak sesuai dengan nilai sikap siswa yang sesungguhnya.

Selanjutnya kendala guru dalam menerapkan penilaian kompetensi pengetahuan .Pada penilaian kompetensi pengetahuan, guru menyatakan bahwa teknik penilaian yang dilakukan guru yaitu tes tertulis, penugasan, dan soal-soal di buku LKS. Masalah dalam tes tertulis dialami oleh guru pada kelas II karena adanya beberapa anak yang tidak bisa mengikuti pelajaran dengan baik sehingga harus diberikan perhatian yang esktra untuk anak-anak tersebut. Serta masalah yang di alami guru yaitu pada teknik penugasan. Pada pembelajaran daring, pada saat guru memberikan tugas kepada siswa, kebanyakan siswa tidak mengumpulkan tugas dan saat dikumpulkan, tugas yang diberikan kebanyakan yang mengerjakan adalah orang tua siswa tidak siswa itu sendiri. Sehingga guru merasa kesulitan untuk memberikan nilai yang sesuai dengan hasil kemampuan siswa sendiri. Sedangkan pada penilaian autentik merupakan nilai nyata hasil kerja siswa itu sendiri.

Dan yang terakhir adalah kendala guru dalam menerapkan penilaian kompetensi keterampilan. Di Sekolah Dasar Negeri 29 Pekanbaru, guru menggunakan teknik Pratik/kinerja, produk serta proyek. Akan tetapi, di dalam penerapannya, guru mengalami kesulitan dalam pengambilan penilaian produk karena dalam proses penilaian ini semua alat dan bahan disedikan oleh guru karena guru tidak mau membebankan pada orang tua siswa, kecuali bahan yang memang mudah didapatkan dirumah maka guru akan meminta siswa untuk membuat produk 
itu dirumah. Sehingga pada saat pembelajaran daring (dalam jaringan) guru hanya mengambil nilai praktek, dan hanya sekali-sekali guru meminta siswa untuk membuat produk. Karena guru tidak mungkin setiap hari membebani orang tua siswa dengan tugas-tugas yang diberikan.

Pada saat dilaksanakan penilaian produk, kebanyakan orang tua siswa yang mengerjakan sehingga nilai yang diberikan tidak efektif. Sedangkan untuk teknik penilaian proyek sendiri, guru menyatakan belum dapat dilaksanakan, karena pembelajaran daring (dalam jaringan), walaupun dilaksanakan hasilnya tidak efektif.

\section{Pembahasan}

Dalam penilaian pembelajaran Kurikulum 2013, guru menilai proses dan hasil belajar peserta didik melalui 3 kompetensi yaitu kompetensi sikap, kompetensi pengetahuan, dan kompetensi keterampilan. Dalam pembahasan ini akan dibahas lebih lanjut mengenai pembahasan hasil penelitian dari kendala guru dalam menerapkan penilaian autentik di SDN 29 Pekanbaru.

\section{a. Penilaian Kompetensi Sikap}

Guru menilai sikap peserta didik menggunakan teknik pengamatan secara langsung (observasi) dan penilaian diri. Pada saat pengamatan secara langsung (observasi) guru mencatat ke dalam jurnal catatan guru. Sedangkan untuk penilaian diri, guru membuat format mengenai penilaian diri siswa dan meminta setiap masingmasing siswa mengisi format penilaian dengan jujur. Hal ini sesuai dengan teknik penilaian sikap yaitu observasi perilaku, penilaian diri, penilaian antar teman, pertanyaan langsung, dan laporan pribadi $^{8}$. Nilai sikap siswa nantinya akan menjadi acuan bagi guru untuk memberikan penilaian seperti nilai pengetahuan siswa. Jika sikap siswa baik akan tetapi nilai pengetahuannya kurang baik, maka nilai sikap siswa akan dijadikan pertimbangan untuk menambahkan nilai pengetahuan siswa yang rendah. Begitupun sebalikanya, jika nilai pengetahuan siswa tinggi akan tetapi sikap siswa buruk, maka guru akan mengurangi nilai pengetahuan siswa.

\section{b. Penilaian Kompetensi Pengetahuan}

Pelaksanaan penilaian kompetensi pengetahuan dilaksanakan selama proses pembelajaran dalam bentuk tes tertulis, penugasan, dan soal-soal yang ada di buku LKS. Pada saat pembelajaran daring (dalam jaringan), guru mengirimkan soal tertulis kepada siswa, lalu siswa menjawab soal tersebut di dalam kertas selembar. Sedangkan mengenai Penilaian Mid Semester, dilaksanakan di akhir tema. Jadi setiap akhir tema akan dilaksanakan Mid semester yang soalnya berbentuk piihan ganda dan essay. Mengenai penilaian UTS dilaksanakan di tengah semester setelah selesai 2 tema, maka sekolah akan mengadakan Ujian Tengah Semester (UTS). Dan yang terakhir adalah penilaian UAS yang dilaksanakan di akhir semester, setelah siswa menyelesaikan semua tema.

Hal ini sesuai dengan teori yang menjelaskan bahwa penilaian pengetahuan terdiri atas : Penilaian Harian (PH), Penilaian Tengah Semester (PTS), dan Penilaian Akhir Semester (PAS). Penilaian Harian (PH) diperoleh dari hasil ulangan harian yang terdiri dari : tes tulis, lisan, dan

\footnotetext{
8 Trianto Ibnu Badar at-Taubany Hadi Suseno, Desain Pengembangan Kurikulum 2013 Di Madrasah (Depok, 2017).
} 
penugasan yang dilaksanakan pada setiap akhir pembelajaran atau Kompetensi Dasar (KD). Penilaian Ulangan Tengah Semester (UTS) diperoleh dari hasil tes tulis yang dilaksanakan pada tengah semester ${ }^{9}$. Materi Ulangan Tengah Semester mencakup seluruh kompetensi yang telah dibelajarkan sampai dengan saat pelaksanaan PTS. Penilaian Akhir Semester (PAS) diperoleh dari hasil tes tulis yang dilaksanakan di akhir semester. Materi PAS mencakup seluruh kompetensi pada semester tersebut.

\section{c. Penilaian Kompetensi Keterampilan}

Guru melaksanakan penilaian keterampilan. Teknik penilaian keterampilan yang dicantumkan guru di dalam silabus adalah praktik/kinerja, proyek, produk. Akan tetapi di dalam pelaksanaannya guru hanya menggunakan teknik praktik/kinerja dan membuat produk. Untuk penilaian proyek guru menyatakan bahwa belum dapat terlaksana, dikarenakan pembelajaran saat ini dilaksanakan secara daring (dalam jaringan). Hal ini hampir sesuai dengan teori yang menjelaskan bahwa penilaian kompetensi keterampilan adalah penilaian yang dilakukan guru untuk mengukur tingkat pencapaian kompetensi keterampilan dari peserta didik yang meliputi aspek imitasi, manipulasi, presisi, artikulasi, dan naturalisasi. Dalam kurikulum 2013 kompetensi keterampilan menjadi kompetensi inti 4 (KI 4). Guru menilai kompetensi keterampilan melalui penilaian kinerja, produk, proyek, dan portofolio ${ }^{10}$.

\footnotetext{
${ }^{9}$ Trianto Ibnu Badar at-Taubany Hadi Suseno.

${ }^{10}$ Kunandar, Penilaian Autentik (Penilaian Hasil Belajar Peserta Didik Berdasarkan Kurikulum 2013.
}

\section{d. Kendala Guru dalam Menerapakan Penilaian Autentik}

Sekolah Dasar Negeri 29 Pekanbaru sudah menerapkan penilaian autentik. Akan tetapi di dalam penerapannya, guru mengalami kendala. Kendala adalah suatu kondisi dimana gejala atau hambatan dan kesulitan menjadi penghalang tercapainya suatu keinginan. Dalam kamus besar bahasa Indonesia Kendala berarti halangan, rintangan, faktor atau keadaan yang membatasi, menghalangi atau mencegah pencapaian sasaran atau kekuatan yang memaksa pembatalan pelaksanaan"11.

Pada penilaian kompetensi sikap, guru menilai sikap siswa menggunakan teknik pengamatan (observasi) dan penilaian diri. Teknik observasi perilaku adalah teknik yang dilakukan secara berkesinambungan melalaui pengamatan perilaku. Sedangkan teknik penilaian diri adalah penilaian yang dilakukan dengan dengan cara meminta siswa untuk mengemukakan kelebihan dan kekurangan dirinya dalam berperilaku' ${ }^{12}$. Akan tetapi pada penerapannya, guru mengalami kesulitan pada teknik penilaian diri. Kesulitan guru adalah jika ada siswa yang kurang tepat pada saat memberikan jawaban pada penilaian diri, dan jika ada siswa yang tidak jujur dalam memberikan jawaban pada penilaian diri. Sehingga nilai yang diberikan tidak sesuai dengan nilai sikap siswa yang sesungguhnya.

Kompetensi sikap perlu mendapat perhatian secara lebih luas karena dari dunia pendidikan inilah tempat anak-

11 D I Sd and Negeri Banda, "Kendala-Kendala Yang Dihadapi Guru Dalam Memanfaatkan Media Berbasis Komputer Di Sd Negeri 10 Banda Aceh," Jurnal Pesona Dasar 2, no. 4 (2016): 21-30.

12 Trianto Ibnu Badar at-Taubany Hadi Suseno, Desain Pengembangan Kurikulum 2013 Di Madrasah. 
anak menghabiskan sebagian besar waktunya. Sangat diharapkan pendidikan sikap mampu membentengi diri anak dari kuatnya arus globalisasi. Dengan pendidikan sikap ini diharapkan kecerdasan emosional anak mampu tumbuh selaras dengan kecerdasaan intelektualnya.

Menurut Kurikulum 2013 membagi kompetensi sikap menjadi dua, yaitu sikap spiritual dan sikap sosial. Sikap spritual yang terkait dengan pembentukan peserta didik yang beriman dan bertakwa, sebagai perwujudan dari menguatnya interaksi vertikal dengan Tuhan Yang Maha Esa dan sikap sosial yang terkait dengan pembentukan peserta didik yang berakhlak mulia, mandiri, demokratis dan bertanggung jawab sebagai perwujudan eksistensi kesadaran dalam upaya mewujudkan harmoni kehidupan ${ }^{13}$.

Selanjutnya dalam menerapkan penilaian kompetensi pengetahuan bahwa teknik penilaian yang digunakan guru yaitu tes tertulis, tes lisan dan penugasan. Guru mengalami kendala dalam menerapkan penilaian kompetensi penegtahuan. Kendala guru adalah dalam tes tertulis dialami oleh guru pada kelas II karena adanya beberapa anak yang tidak bisa mengikuti pelajaran dengan baik sehingga harus diberikan perhatian yang esktra untuk anak-anak tersebut. Tes tertulis adalah tes di mana soal dan jawaban yang diberikan kepada siswa dalam bentuk tulisan. Dalam menjawab soal peserta didik tidak selalu merespon dalam bentuk menulis jawaban tetapi dapat juga dalam

\footnotetext{
${ }^{13}$ Gede Gunatama Yohana Herlina Mbindi, I Made Sutama, "Penilaian Kompetensi Sikap Dalam Pembelajaran Bahasa Indonesia Berdasarkan Kurikulum 2013 Di Kelas X Smk Ti Bali Global Singaraja," Journal Jurusan Pendidikan Bahasa Dan Sastra Indonesia 7, no. 2 (2013): 2.
}

bentuk yang lain seperti memberi tanda, mewarnai, menggambar, dan lain sebagainya ${ }^{14}$. Serta masalah yang di alami guru yaitu pada teknik penugasan. Pada pembelajaran daring,pada saat guru memberikan tugas kepada siswa, kebanyakan siswa tidak mengumpulkan tugas dan saat dikumpulkan, tugas yang diberikan kebanyakan yang mengerjakan adalah orang tua siswa tidak siswa itu sendiri. Sehingga guru merasa kesulitan untuk memberikan nilai yang sesuai dengan hasil kemampuan siswa sendiri. Sedangkan pada penilaian autentik merupakan nilai nyata hasil kerja siswa itu sendiri. Penugasan adalah pemberian tugas kepada siswa untuk mengukur dan meningkatkan pengetahuan. Penugasan dapat berupa pekerjaan rumah dan/atau proyek yang dikerjakan secara individu atau kelompok sesuai dengan karakteristik tugas $^{15}$.

Dan yang terakhir adalah kendala guru dalam menerapkan penilaian kompetensi keterampilan. Di Sekolah Dasar Negeri 29 Pekanbaru, guru menggunakan teknik Pratik/kinerja, produk serta proyek. Hal ini hampir sesuai dengan yaitu penilaian keterampilan dapat dilakukan dengan berbagai teknik antara lain penilaian praktik/kinerja, proyek, produk dan portofolio $^{16}$. Akan tetapi, di dalam penerapannya, guru mengalami kesulitan dalam pengambilan penilaian

\footnotetext{
14 Nurjanah and Noni Marlianingsih, "Analisis Butir Soal Pilihan Ganda Dari Aspek Kebahasaan," Faktor Jurnal Ilmu Kependidikan 2, no. 1 (2015): 69-78.

15 Nana Sutarna, "Penerapan Metode Penugasan Untuk Meningkatkan Kemampuan Memahami Peta Pada Siswa Sekolah Dasar," Jurnal Geografi Gea 16, no. 1 (2016): 34.

${ }^{16}$ Kunandar, Penilaian Autentik (Penilaian Hasil Belajar Peserta Didik Berdasarkan Kurikulum 2013.
} 
produk karena dalam proses penilaian ini semua alat dan bahan disedikan oleh guru karena guru tidak mau membebankan pada orang tua siswa, kecuali bahan yang memang mudah didapatkan dirumah maka guru akan meminta siswa untuk membuat produk itu dirumah. Sehingga pada saat pembelajaran daring (dalam jaringan) guru hanya mengambil nilai praktek, dan hanya sekali-sekali guru meminta siswa untuk membuat produk. Karena guru tidak mungkin setiap hari membebani orang tua siswa dengan tugas-tugas yang diberikan. Dan pada saat dilaksanakan penilaian produk, kebanyakan orang tua siswa yang mengerjakan sehingga nilai yang diberikan tidak efektif. Sedangkan untuk teknik penilaian proyek sendiri, guru menyatakan belum dapat dilaksanakan, karena pembelajaran daring (dalam jaringan), walaupun dilaksanakan hasilnya tidak efektif.

Penilaian produk adalah penilaian terhadap proses pembuatan dan kualitas suatu produk. Penilaian produk meliputi seperti penilaian kemampuan siswa membuat produkproduk teknologi dan seni, seperti makanan, pakaian, hasil karya seni (patung, lukisan, gambar), barangbarang tersebut yang dapat terbuat dari kayu, keramik, pelastik, dan logam ${ }^{17}$.

\section{SIMPULAN}

Berdasarkan hasil penelitian dan pembahasan, maka dapat di ambil kesimpulan bahwa Sekolah Dasar Negeri 29 Pekanbaru telah menerapkan penilaian autentik untuk menilai hasil

\footnotetext{
17 Endang Sri Maruti and Naniek Kusumawati, "Proses Pengembangan Asesmen Alternatif Berupa Penilaian Produk Pada Mata Kuliah Pembelajaran Bahasa Jawa Di Sd," Jurnal Pendidikan Dasar Perkhasa: Jurnal Penelitian Pendidikan Dasar 4, no. 2 (2018): 189-99.
}

belajar siswa. Akan tetapi di dalam penerapannya, guru mengalami kendala. Kendala guru dalam menerapkan penilaian autentik terbagi menjadi 3 yaitu pertama, penilaian kompetensi sikap di Sekolah Dasar Negeri 29 Pekanbaru menggunakan teknik penilaian diri dan pengamatan (observasi). Kendala yang di alami guru adalah jika ada siswa yang kurang tepat pada saat memberikan jawaban pada penilaian diri, dan jika ada siswa yang tidak jujur dalam memberikan jawaban pada penilaian diri. Sehingga nilai yang diberikan tidak sesuai dengan nilai sikap siswa yang sesungguhnya.

Kedua, penilaian kompetensi pengetahuan di Sekolah Dasar Negeri 29 Pekanbaru menggunakan teknik tes tertulis, penugasan dan soal-soal yang ada di buku LKS, serta nilai dari MID Semester, UTS dan UAS. Kendala guru dalam menerapakan penilaian kompetensi pengetahuan adalah dalam tes tertulis dialami oleh guru pada kelas II karena adanya beberapa anak yang tidak bisa mengikuti pelajaran dengan baik sehingga harus diberikan perhatian yang esktra untuk anak-anak tersebut. Serta kendala yang di alami guru yaitu pada penggunaan teknik penugasan. Pada pembelajaran daring, pada saat guru memberikan tugas kepada siswa, kebanyakan siswa tidak mengumpulkan tugas dan saat dikumpulkan, tugas yang diberikan kebanyakan yang mengerjakan adalah orang tua siswa tidak siswa itu sendiri.

Ketiga, Penilaian Kompetensi Keterampilan di Sekolah Dasar Negeri 29 Pekanbaru dilaksanakan menggunakan teknik praktik/kinerja dan produk. Kendala guru dalam melakukan penilaian kompetensi keterampilan yaitu guru mengalami kesulitan dalam pengambilan penilaian produk karena dalam proses penilaian 
ini semua alat dan bahan disedikan oleh guru karena guru tidak mau membebankan pada orang tua siswa, kecuali bahan yang memang mudah didapatkan dirumah maka guru akan meminta siswa untuk membuat produk itu dirumah. Sehingga pada saat pembelajaran daring (dalam jaringan) guru hanya mengambil nilai praktek, dan hanya sekali-sekali guru meminta siswa untuk membuat produk. Karena guru tidak mungkin setiap hari membebani orang tua siswa dengan tugas-tugas yang diberikan.

Dan pada saat dilaksanakan penilaian produk, kebanyakan orang tua siswa yang mengerjakan sehingga nilai yang diberikan tidak efektif. Sedangkan untuk teknik penilaian proyek sendiri, guru menyatakan belum dapat dilaksanakan, karena pembelajaran daring (dalam jaringan), walaupun dilaksanakan hasilnya tidak efektif.

\section{DAFTAR PUSTAKA}

Kunandar. 2015. Penilaian Autentik (Penilaian Hasil Belajar Peserta Didik Berdasarkan Kurikulum 2013. Jakarta:Raja Grafindo Persada.

Larasanty, N. K. Puspa Indah.2020.

"Meningkatkan Kompetensi

Pengetahuan IPA Dengan

Menggunakan Model

Pembelajaran Predict Observe Explain Berbasis Berpikir Kreatif." Mimbar Ilmu 25, no. Vol 25, No 3: 391-400.

Maruti, Endang Sri, and Naniek Kusumawati. 2018. "Proses Pengembangan Asesmen Alternatif Berupa Penilaian Produk Pada Mata Kuliah Pembelajaran Bahasa Jawa Di Sd." JURNAL PENDIDIKAN DASAR PERKHASA: Jurnal Penelitian Pendidikan Dasar 4, no. 2 : 189-
99.

Nurjanah, and Noni Marlianingsih. 2015. "Analisis Butir Soal Pilihan Ganda Dari Aspek Kebahasaan." Faktor Jurnal Ilmu Kependidikan 2, no. $1: 69-78$.

Ruslan, Tati Fauziah, and Tuti Alawiyah. 2016. "Kendala Guru Dalam Menerapkan Penilaian Autentik Di SD Kabupaten Pidie." Jurnal Ilmiah Mahasiswa Pendidikan Guru Sekolah Dasar 1, no. $1: 147-57$.

Sd, D I, and Negeri Banda. 2016. "Kendala-Kendala Yang Dihadapi Guru Dalam Memanfaatkan Media Berbasis Komputer Di Sd Negeri 10 Banda Aceh." Jurnal Pesona Dasar 2, no. 4 : 21-30.

Sutarna, Nana. 2016. "Penerapan Metode Penugasan Untuk Meningkatkan Kemampuan Memahami Peta Pada Siswa Sekolah Dasar." Jurnal Geografi Gea 16, no. 1: 34 .

Trianto Ibnu Badar at-Taubany Hadi Suseno. 2017. Desain Pengembangan Kurikulum 2013 Di Madrasah. Depok : PT Kharisma Putra Utama.

Warsono. 2017. "Guru: Antara Pendidik, Profesi, Dan Aktor Sosial." The Journal of Society $\mathcal{E}$ Media 1, no. 1 : 1.

Yohana Herlina Mbindi, I Made Sutama, Gede Gunatama. 2013. "Penilaian Kompetensi Sikap Dalam Pembelajaran Bahasa Indonesia Berdasarkan Kurikulum 2013 Di Kelas X Smk Ti Bali Global Singaraja." Journal Jurusan Pendidikan Bahasa Dan Sastra Indonesia 7, no. $2: 2$.

Yuyun Dwi Haryanti, Sapriya, Tegar Pamubdhi. 2021. "Jurnal Cakrawala Pendas PENGEMBANGAN MODEL 
PENILAIAN AUTENTIK PADA Abstrak Pendahuluan Kurikulum Yang Berlaku Saat Ini Di Indonesia Adalah Kurikulum 2013 Atau Dengan Sebutan Menggunakan Pengetahuan , Menampilkan Sikap , Dan Keterampilan Yang Diperoleh Mel" 7, no. $1:$ 27-39. 